\title{
REGULASI LEMBAGA-LEMBAGA FASILITATOR SEBAGAI PENENTU ARAH KEBIJAKAN OPERASIONAL BANK SYARIAH
}

\author{
Haryono $^{1}$, Raudya Pertiwi ${ }^{2}$ \\ ${ }^{1}$ Sekolah Tinggi Agama Islam Al Hidayah Bogor \\ ${ }^{2}$ Sekolah Tinggi Agama Islam Al Hidayah Bogor \\ email: haryono.staialhidayahbogor@gmail.com \\ email: raudyp97@gmail.com
}

\begin{abstract}
This study aims to examine the role of Islamic banking facilitator institutions and their function on Islamic banking in carrying out the management system and the working system of Islamic banks. In this study the authors used an explanatory qualitative research method and data obtained based on official sources related to information about the role and function of facilitating institutions with Islamic banking financial institutions as well as from book reference sources and other relevant references. The author found that overall the Islamic banks facilitator institution plays an important role as an institution that supports the activities of Islamic banks in a proportional and orderly manner. And the authors found that according to the LPS information up to now there has not been an Islamic bank in particular that experienced a failed bank or a bank that needed to be saved. The essence of the role and function of the facilitating institution is very closely related to financial institutions, especially Islamic banks. And each institution has different authorities, functions and duties in supervising, overseeing, protecting, solving problems, issuing fatwas related to bank products and regulations regarding work systems in Islamic banking. The main function of an Islamic bank facilitator institution is to support the business activities of an Islamic bank in order to run effectively, in an orderly manner, and in accordance with Islamic principles.

Keywords: Islamic Banks, Facilitator Institutions, Banking Systems.
\end{abstract}

\begin{abstract}
ABSTRAK
Penelitian ini bertujuan untuk mengkaji peran lembaga-lembaga fasilitator bank syariah dan fungsinya terhadap kebijakan kegiatan usaha bank syariah di Indonesia dalam menjalankan sistem manajemen dan sistem kerja bank syariah. Dalam penelitian ini penulis menggunakan metode penelitian kualitatif eksplanatif, data diperoleh dari sumber-sumber resmi yang terkait informasi mengenai peran dan fungsi lembaga fasilitator dengan lembaga keuangan perbankan syariah juga dari sumber referensi buku dan referensi lainnya yang relevan. Penulis menemukan bahwa secara keseluruhan lembaga fasilitator bank syariah berperan penting sebagai lembaga yang mendukung berjalannya kegiatan bank syariah secara proporsional dan tertib aturan. Dan penulis menemukan bahwa menurut informasi LPS hingga saat ini belum ada bank syariah khususnya yang mengalami bank gagal atau bank yang perlu diselamatkan keberadaannya. Inti dari peran dan fungsi lembaga fasilitator amat erat kaitannya terhadap lembaga keuangan khususnya bank syariah. Dan setiap lembaga memiliki wewenang, fungsi dan tugas yang berbeda dalam mengawasi, mengawal, melindungi, menyelesaikan permasalahan, menerbitkan fatwa terkait produk bank dan peraturan mengenai sistem kerja pada perbankan syariah. Fungsi utama lembaga fasilitator bank syariah adalah mendukung kegiatan usaha bank syariah agar berjalan secara efektif, sehat tertib aturan, dan sesuai dengan prinsip syariah.
\end{abstract}

Kata Kunci: bank syariah, l embaga Fasilitator, Sistem Perbankan. 


\section{A. PENDAHULUAN}

Islam adalah agama yang membawa rahmat bagi semesta alam (rahmatan lil 'alamin). Ajarannya mencangkup seluruh aspek kehidupan, tidak terkecuali bidang ekonomi yang dalam perkembangannya saat ini dan mendatang dirasakan semakin kompleks. ${ }^{1}$ Lembaga keuangan, khususnya bank syariah kini tengah popular kehadirannya di Indonesia dengan pelopor utamanya adalah Bank Muamalat yang didirikan pada tahun 1991. Kedudukan bank syariah di Indonesia memiliki payung hukum yang kuat sejak diterbitkannya Undang-Undang Nomor 21 Tahun 2008. Dengan adanya undang-undang tersebut perbankan syariah semakin berkembang di dunia perbankan dan perekonomian di Indonesia. Seperti yang yang telah diketahui lembaga keuangan seperti bank dan non-bank khususnya pada lembaga keuangan, bank syariah memiliki lembagalembaga penjamin yang berhubungan, mendukung dan mengawasi setiap kegiatan pada lembaga keuangan. Banyak sekali lembaga fasilitator yang memiliki peranan penting untuk mendukung beroperasinya bank syariah, dan untuk menjamin bahwa kegiatan usaha bank syariah sesuai dengan

1 Sholihin, Ahmad Ifham. 2010). Pedoman Umum Lembaga Keuangan Syariah. Jakarta: PT Gramedia. hlm.50. prinsip syariah yang bersih dari unsur riba, gharar, maisir, haram, dan zalim. Lembaga-lembaga yang menjadi fasilitator terhadap segala bentuk kegiatan perbankan syariah memiliki banyak sekali hubungan dan fungsi-fungsi yang berkaitan erat. Lembaga fasilitator tersebut meliputi Bank Indonesia (BI), Otoritas Jasa Keuangan (OJK), Dewan Syariah Nasional Majlis Ulama Indonesia (DSN MUI), Ikatan Akuntansi Indonesia (IAI), Dewan Pengawas Syari'ah (DPS), Badan Abritrase Syari'ah Nasional (Basyarnas), Lembaga Penjamin Simpanan (LPS), dan Jamkrindo. Peran dan fungsi lembaga-lembaga fasilitator bank syariah sangat menentukan sekali kegiatan operasional bank syariah agar dapat berjalan dengan baik, tertib, dan efektif. Memahami lembaga-lembaga fasilitator bank syariah menjadi penting untuk mengetahui posisi dan kedudukan bank syariah sebagai lembaga keuangan yang syarat dengan aturan-aturan yang mengikat. Penelitian ini bertujuan untuk menjelaskan fungsi dan peran lembaga fasilitator bank syariah terhadap bank syariah. Sehingga dengan demikian masyararkat akan mengetahui dengan jelas kedudukan bank syariah sebagai lembaga intermediasi keuangan dalam menjalankan kegiatan usahanya mulai dari 
penghimpunan dana, penyaluran pembiayaan, dan jasa bank syariah.

\section{B. TINJAUAN PUSTAKA}

Sebagai lembaga intermediasi keuangan, bank syariah menjalankan kegiatan usahanya dalam penghimpunan dana, penyaluran pembiayaan, dan jasa perbankan menggunakan akad-akad dalam muamalah Islam. Kapasistas bank syariah sebagai lembaga keuangan tentunya berbeda dengan pelaku bisnis yang bisa langsung terjun ke sektor riil, pelaku bisnis dalam hal ini adalah individu atau badan usaha seperti UMKM lebih leluasa bertransaksi dengan menggunakan akadakad muamalah bisnis dalam Islam. Sedangkan bank syariah sebagai lembaga intermediasi dibatasi, dan diawasi oleh aturan-aturan tertentu yang bersifat mengikat. Akad-akad yang digunakan bank syariah dalam menjalankan kegiatan usahanya harus menyesuaikan dengan sistem perbankan yang lebih dahulu terbangun, sehingga akad-akad tersebut harus dirumuskan agar dapat mengikuti model kegiatan usaha pada bank syariah sebagai lembaga keuangan yang berfungsi intermediasi. Oleh karenanya UndangUndang Nomor 21 Tahun 2008 menunjuk Dewan Syariah Nasional, Majelis Ulama
Indonesia (DSN-MUI) sebagai lembaga resmi yang menerbitkan fatwa-fatwa khusus terkait kegiatan usaha bank syariah. Fatwa DSN-MUI kemudian menjadi legalitas syariah bank syariah. Kedudukan fatwa DSN-MUI dalam kegiatan usaha bank syariah menjamin bahwa setiap transaksi yang dilakukan terbebas dari unsur riba, gharar, dan maisir.

Demikian pula dengan aturan-aturan dari lembaga fasilitator yang lainnya.

\section{METODE PENELITIAN}

Jenis penelitian ini adalah kualitatif eksplanatif dengan menggunakan pendekatan fenomenologi. Teknik pengumpulan data berupa observasi dari data-data skunder yang publish oleh lembaga-lembaga fasilitator bank syariah di website-website resmi. Data-data tersebut dilengkapi dengan referansi dari buku-buku, dan jurnal penelitian terdahulu yang relevan. Data dianalisis secara deskriptif dan diinterpretasikan secara umum untuk menggambarkan fungsi dan peran lembaga-lembaga fasilitator bank syariah pada kegiatan usaha bank syariah. Penelitian ini berusaha menjelaskan secara detail hubungan dan peran lembaga fasilitator bank syariah dengan bank syariah, sehingga tidak mengesankan 
bahwa seolah-olah bank syariah berdiri sendiri. Penelitian ini mendalami sejauh mana aturan-aturan lembaga fasilitator bank syariah dalam mempengaruhi kebijakan kegiatan usaha bank syariah.

\section{PEMBAHASAN}

Sistem keuangan di Indonesia dilaksanakan dengan dual system, yaitu konvensional dan syariah. ${ }^{2}$ Namun fokus kali ini ialah pada perbankan syariah mengenai hubungan dan fungsi lembaga fasilitator terhadap perbankan syariah. Akan diuraikan sebagai berikut:

\section{Bank Indonesia (BI)}

Bank Indonesia merupakan induk dari semua bank dan memiliki tugas mencetak uang resmi negara dalam bentuk rupiah, dan memelihara kestabilan nilai rupiah. Selain itu Bank Indonesia memegang tanggung jawab akan beredarnya uang di Indonesia yang menjadi acuan untuk menjaga kestabilan uang yang beredar agar tidak terjadi inflansi. ${ }^{3}$ Begitupun ada

\footnotetext{
${ }^{2}$ Andri Soemitra. (2010). Bank dan Lembaga Keuangan Syariah. Jakarta: Kencana. hlm. 40.

${ }^{3}$ Inflasi (kemerosotan nilai mata uang) terjadi karena lima hal; bertambahnya uang yang beredar (quantity theory inflation), kenaikan biaya produksi (cost push inflation), kenaikan penawaran dan permintaan (mixed inflation), dan terjadinya struktural ekonomi yang kaku (structural economy inflation). Dalam hal ini Bank Indonesia sebagai bank sentral harus segera melakukan pencegahan dengan kebijakan yang tepat.
}

hubungannya dengan lembaga keuangan bank seperti perbankan syariah. Ini menjadi fokus utama Fungsi dari Bank Indonesia terhadap bank syariah yaitu mengatur sistem kelancaran keuangan di bank syariah, mengatur sistem dan mengawasi kegiatan bank-bank syariah. Fungsi lainnya adalah memberi bantuan terhadap bank-bank syariah yang mengalami krisis atau kebangkrutan. Jika bank-bank syari'ah dalam naungan Bank Indonesia mengalami krisis atau kebangkrutan maka Bank Indonesia akan membantu dengan memberikan bantuan pendanaan agar bank tersebut dapat kembali menjalankan kegiatan usahanya dan dapat menata kembali sistem keuangannya. Bank Indonesia juga memiliki wewenang memberikan izin atau mencabut izin usaha bank syariah.

Perbankan syariah memiliki hubungan dengan Bank Indonesia, mengapa? Bank Indonesia sebagai otoritas moneter dan stabilitas sistem keuangan tetap berperan serta dalam pengembangan ekonomi dan keuangan perbankan syariah bersama dengan stakeholder terkait, dengan mengacu pada prinsip dan nilai-nilai

https://www.jurnal.id/id /blog/2017 -5-faktorpenyebab-terjadinya-inflasi/, Lima Faktor Terjadinya Inflasi, diakses pada tanggal 26 Maret 2020. 
ekonomi dan keuangan syariah yang berdimensi keadilan, transparansi, produktifitas dan tata kelola yang baik (governance) ${ }^{4}$

\section{Otoritas Jasa Keuangan (OJK)}

Otoritas jasa keuangan (OJK) adalah lembaga yang independen yang bebas dari campur tangan pihak lain. OJK memiliki fungsi, tugas, dan wewenang dalam pengaturan, pengawasan, pemeriksaan, dan penyelidikan sebagaimana yang dimaksud dalam undang-undang. ${ }^{5}$ Ide awal pembentukan OJK itu sendiri agar lembaga-lembaga keuangan terlebih dalam sektor jasa dapat terlaksana secara adil, terbuka, transparan, teratur, dan mampu menciptakan sebuah sistem keuangan yang stabil dan melindungi nasabah sebagai konsumen dari lembaga keuangan syariah tersebut. Namun ada fokus utama dalam hubungan dan fungsi OJK terhadap lembaga keuangan syariah berupa pengaturan dan pengawasan akan perizinan, penyelidikan, izin pendirian lembaga keuangan bank syariah, perilisan kantor bank baru, rencana kerja,

\footnotetext{
Situs resmi Bank Indonesia, https://www.bi.go.id.

5 Undang-Undang Republik Indonesia nomer 21 Tahun 2011 tentang Otoritas Jasa Keuangan BAB I Pasal 1.
}

kepemilikan asset, sistem kepengurusan dan SDM, merger, dan berwewenang mencabut izin lembaga keuangan bank syariah dan berhak memberikan sanksi administratif terhadap pihak yang melakukan pelanggaran UU dalam pelaksanaan kegiatan ekonomi.

Lembaga keuangan syariah bersama OJK telah memperlihatkan bahwa industri perbankan syariah mengalami pertumbuhan yang semakin pesat. Pengawasan terhadap terhadap perbankan syariah lebih komprehensif dan efektif dilakukan seiring dengan bertambahnya pelaku pasar, varian produk atau jasa layanan, serta kemajuan teknologi yang semakin inovatif dan kompleks. Hal ini demi terwujudnya sistem perbankan syariah yang sehat dan guna mendukung pencapaian stabilitas sistem keuangan dan pertumbuhan perekonomian secara umum. ${ }^{6}$

\section{Dewan Syariah Nasional Majelis Ulama Indonesia (DSN-MUI)}

Dewan Syariah Nasional Majelis Ulama Indonesia atau yang lebih dikenal dengan sebutan DSN- MUI merupakan lembaga yang didirikan oleh MUI pada tahun 1999 yang memiliki fungsi untuk

\footnotetext{
6 Hasbi Hasan. (2012). Efektivitas Pengawasan Otoritas Jasa Keuangan Terhadap Lembaga Perbankan Syariah. Jurnal Legislasi Indonesia, 9/3. hlm. 385.
} 
menjalankan tugas MUI dalam memajukan ekonomi umat, serta menangani masalah yang berkaitan dengan aktivitas lembaga keuangan syariah bank dan non-bank.

DSN-MUI juga berperan serta untuk membantu lembaga-lembaga seperti Bank Indonesia, Departemen Keuangan dan lembaga-lembaga lainnya dalam membentuk peraturan atau ketentuan untuk lembaga keuangan syariah. ${ }^{7}$ Salah satu tugas pokok DSN-MUI adalah mengkaji, menggali dan merumuskan nilai dan prinsip-prinsip hukum Islam (syariah) dalam bentuk fatwa untuk dijadikan pedoman dalam kegiatan transaksi di lembaga keuangan syariah. ${ }^{8}$ Lebih jelasnya DSN-MUI bertugas: ${ }^{9}$

a. Mengembangkan penerapan nilainilai syariah dalam setiap kegiatan perekonomian khusunya pada kegiatan sehari-hari dan kegiatan keuangan.

b. Menetapkan fatwa untuk segala bentuk kegiatan keuangan.

c. Menetapkan fatwa akan produk dan jasa keuangan syariah.

7 Ahmad Ifham Sholihin. (2010). Pedoman Umum Lembaga Keuangan Syariah. Jakarta: PT Gramedia Pustaka Utama. hlm. 51.

${ }^{8}$ Andri Soemitra. 2010). hlm. 42.

${ }^{9}$ Ahmad Ifham Sholihin. (2010). hlm. 51. d. Melakukan pengawasan akan fatwa yang telah dikeluarkan.

DSN juga memiliki mekanisme berkerja seperti:

a. Memberlakukan rancangan fatwa yang diajukan oleh Badan Pelaksana Harian DSN-MUI.

b. Melakukan rapat pleno per tiga bulan sekali bila diperlukan.

c. Membuat pernyataan yang dimasukan ked alam laporan tahunan (annual report) yang memberitahukan bahwa lembaga keuangan syariah yang bersangkutan telah atau tidak memenuhi ketentuan syariah berdasarkan fatwa yang dikeluarkan oleh DSN-MUI.

\section{Dewan Pengawas Syariah (DPS)}

Secara ringkas bahwa Dewan Pengawas Syariah atau yang dikenal sebagai DPS merupakan wakil dari DSNMUI untuk lembaga-lembaga keuangan syariah untuk melakukan pengawasan pada lembaga keuangan syariah yang berada pada pengawasannya, yang memiliki kewajiban untuk memberikan usulan pengembangan lembaga keuangan syariah kepada pimpinan lembaga keuangan yang bersangkutan dan kepada DSN. Juga melakukan pelaporan perkembangan 
produk dan sistem operasional lembaga keuangan syariah yang setidaknya berlangsung dua kali dalam satu tahun anggaran.

DPS memiliki tugas dan tanggung jawab yang sangat signifikan pada bank syariah. Di antara tugas DPS adalah sebagai berikut: 1) DPS menilai dan memastikan pemenuhan syariah pada seluruh kegiatan usaha bank syariah, mulai dari penghimpunan dana, penyaluran pembiayaan, dan jasa keuangan bank syariah. Setiap produk bank syariah harus berdasarkan fatwa DSN-MUI. 2) mengawasi pengembangan produk baru bank syariah agar sesuai dengan fatwa DSN-MUI, kemudian DPS membuat opini dan memintakan fatwa untuk produk baru bank syariah tersebut. 3) DPS melakukan review secara berkala atas pemenuhan prinsip syariah. Pelaksanaan tugas DPS sepenuhnya diatur dalam laporan GCG (Good Corporate Governance) bank syariah yang dilaporkan setiap satu tahun sekali. Laporan GCG memperkuat posisi bank syariah sebagai lembaga keuangan yang memiliki tata kelola perusahaan yang baik dengan indikator adanya transparansi, profesionalisme, kewajaran, dan tanggungjawab.
Dalam melaksanakan tugasnya DPS dibantu oleh Departemen Shariah Compliance bank syariah yang memiliki fungsi pengawasan secara berjenjang mulai dari kantor pusat, kantor cabang area, kantor cabang utama, sampai kantor cabang pembantu. Departemen Shariah Compliance memastikan setiap dokumen akad bank syariah sudah comply. Selain itu DPS juga mengadakan pelatihan dan seminar terkait akad-akad produk bank syariah yang dilaksanakan di setiap kantor cabang. Pembianaan dilakukan oleh DPS pada saat DPS melakukan uji petik yang setiap tahunnya dilaksanakan di delapan atau sembilan kantor cabang bank syariah di seluruh Indonesia. Kegiatan pengawasan yang dilakukan oleh DPS berjalan secara sistematis dan dituangkan di dalam laporan pengawasan setiap satu semester sekali dan dimuat secara detail di laporan GCG bank syariah. Laporan GCG bank syariah yang memuat laporan DPS dipublish secara rutin oleh bank syariah di website resmi mereka setiap tahun, sehingga dapat diakses dengan mudah oleh masyarakat.

\section{Ikatan Akuntan Indonesia (IAI)}

Ikatan Akuntan Indonesia atau biasa disingkat IAI merupakan organisasi profesional yang menaungi akuntan professional di Indonesia, senantiasa 
berperan aktif dalam meningkatkan pertumbuhan ekonomi syariah di Indonesia. IAI menyadari bahwa transaksi syariah memiliki keunikan tersendiri sehingga membutuhkan adanya standar akuntansi syariah. Maka dari itu Dewan Standar Akuntansi Keuangan (DSAK) IAI menerbitkan standar akuntansi syariah pertama di Indonesia. ${ }^{10}$

Komite Akuntansi Syariah (KAS) merupakan komite yang dibentuk oleh IAI untuk merumuskan standar akuntansi syariah. Komite ini dibentuk sejak Oktober 2005 dari berbagai unsur, antara lain Dewan Standar Akuntansi KeuanganIkatan Akuntansi Indonesia (DSAK-IAI), DSN-MUI, Bank Indonesia, BAPEPAM, Asosiasi Perbankan Syariah Indonesia (ASBISINDO), Asosiasi Asuransi Syariah Indonesia (AASI) dan akademisi. ${ }^{11}$

Sampai tahun 2007 KAS-IAI telah menghasilkan draf sesuai kaidah syariah yang kemudian disahkan oleh DSAK dan mulai berlaku pada tanggal 1 Januari tahun 2008 atau pembukuan tahun yang berakhir tahun 2008. Berikut merupakan daftar ED (Exposure Draf) Standar Akuntansi Keuangan bagi perbankan syariah:

\footnotetext{
${ }^{10}$ Situs resmi IAI. https://www.iaiglobal.or.id/

11 Rizal Yaya et.al. (2009). Akuntansi Perbankan Syariah Teori dan Praktik Kontemporer. Jakarta. hlm. 28.
}

a. ED Kerangka Dasar Penyususnan dan Pengkajian Laporan Keuangan Syariah.

b. ED PSAK 101 (Revisi 2006) tentang pengkajian Laporan Keuangan Syariah.

c. ED PSAK 102 (Revisi 2006) tentang Akuntansi Murabahah (jual beli).

d. ED PSAK 103 (Revisi 2006) tentang Akuntansi Salam.

e. ED PSAK 104 (Revisi 2006) tentang Akuntansi Istishna'

f. ED PSAK 105 (Revisi 2006) tentang Akuntansi Mudharabah (bagi hasil).

g. ED PSAK 106 (Revisi 2006) tentang Akuntansi Musyarakah (kemitraan). ${ }^{12}$

Pembentukan SAK-syariah bertujuan agar perekonomian syariah di Indonesia dapat berkembang dan berjalan dengan baik. Dalam laporan keuangan, bank syariah memiliki banyak sekali akad-akad syariah dalam produknya. Masing-masing akad memiliki kekhususan dalam menentukan pendapatan atau keuntungan, sehingga diperlukan PSAK-PSAK yang mendukung laporan keuangan syariah pada bank syariah. Pengelolaan laporan

\footnotetext{
${ }^{12}$ Situs resmi IAI. https://iaiglobal.org.id.
} 
keuangan syariah yang patuh (comply) pada PSAK-PSAK tersebut dapat memperkuat trust bank syariah pada masyarakat. PSAK akuntansi syariah didasari oleh kerangka dasar syariah. Tujuan laporan keuangan syariah yang menggunakan akuntansi syariah adalah sebagai berikut:

a. Meningkatkan kepatuhan terhadap prinsip syariah dalam semua transaksi dan kegiatan usaha.

b. Informasi kepatuhan entitas syari'ah terhadap prinsip syariah, bila ada informasi aktiva, kewajiban, pendapatan dan beban yang tidak sesuai dengan prinsip syariah dan bagaimana perolehan dan penggunaannya.

c. Informasi untuk membantu mengevaluasi pemenuhan tanggung jawab entitas syariah terhadap amanah dalam mengamankan dana, menginvestasikannya pada tingkat keuntungan yang layak.

d. Informasi mengenai tingkat keuntungan investasi yang diperoleh penanam modal dan pemilik dana syirkah temporer; dan informasi mengenai pemenuhan kewajiban (obligation) fungsi sosial entitas syariah.

\section{Badan Arbitrase Syariah Nasional (Basyarnas)}

Basyarnas atau Badan Arbitrase Syariah Nasional merupakan lembaga yang membantu penyelesaian perselisihan antara Lembaga Keuangan Syariah dengan Nasabah sesuai dengan tata cara hukumhukum syariah. Biasanya nasabah yang memiliki perselisihan dengan lembaga keuangan syariah akan datang ke basyarnas sebelum datang ke pengadilan negeri karena cara ini merupakan cara yang paling efektif dan efisien.

Pembentukan Basyarnas dalam undang-undang nomor 30 tahun 1999 tentang Arbitrase dan Alternatif Penyelesaian Sengketa. Dan melalui Surat Keputusan Dewan Pimpinan MUI No. Kep-09/MUI/XII/2003 tanggal 24 Desember 2003 mengenai Basyarnas merupakan lembaga hukum (Arbitrase syariah) di Indonesia yang memiliki wewenang untuk memeriksa dan memutuskan sengketa muamalah yang muncul dalam bidang perdagangan, jasa, industri dan keuangan. Bahkan di seluruh fatwa DSN MUI mengenai perihal hubungan muamalah (perdata) senantiasa diakhiri dengan ketentuan: "jika salah satu pihak tidak menunaikan kewajibannya atau tidak terjadi perselisihan di antara kedua 
belah pihak, maka penyelesaiannya dilakukan melalui Badan Arbitrase Syariah Nasional setelah tidak tercapai kesepakatan melalui musyawarah. ${ }^{13}$

Posisi Basyarnas dalam penyelesaian sengketa di bank syariah sangat vital, mengingat banyak sekali silang sengketa yang terjadi antara nasabah dengan bank syariah. Silang sengketa tersebut acap kali terjadi dikarenakan adanya ketidakjelasan dan ketidakpahaman nasabah terhadap pembiayaan produk-produk bank syariah. Dalam hal ini Basyarnas berkepentingan untuk menyelesaikan sengketa yang terjadi menurut hukum syariah. Namun demikian jarang sekali nasabah yang memiliki sengketa dengan bank syariah menggunakan Basyarnas sebagai media penyelesai sengketa.

\section{Lembaga Penjamin Simpanan (LPS)}

Sebagaimana diamanatkan dalam UU No.24 Tahun 2004 tentang Lembaga Penjamin Simpanan Lembaga Penjamin Simpanan berkewajiban untuk terus memperluas hubungan dengan

\footnotetext{
13 Majelis Ulama Indonesia "Sejarah Basyarnas", situs resmi https://www.mui.org.id/2009.
}

stockholders untuk menjelaskan pelaksanaan semua tugas dan fungsinya. ${ }^{14}$

Penjamin simpanan yang dijalankan oleh LPS juga menjamin simpanan nasabah bank syariah. Dana masyarakat yang ditempatkan oleh nasabah pada bank syariah, yaitu berupa giro dan tabungan dengan akad wadiah, ataupun tabungan dan deposito dengan akad mudharabah yang risikonya ditanggung oleh pihak bank, serta jenis simpanan lain yang diizinkan oleh Lembaga Pengawas Perbankan juga dijamin oleh LPS Sesuai dengan ketentuan yang berlaku. ${ }^{15}$

LPS memiliki tugas lain selain menjalankan penjaminan simpanan nasabah pada bank syariah, yaitu merumuskan, menetapkan dan melaksanakan kebijakan penyelesaian Bank Gagal yang tidak berdampak sistematik. Dan melaksanakan penanganan Bank Gagal yang berdampak sistemik. Yang dimaksudkan Bank Gagal di sini adalah Bank yang tidak mampu mempertanggung jawabkan segala bentuk simpanan nasabah dan mempertanggung jawabkan risiko-risiko yang terjadi pada Bank tersebut. Meski begitu, hingga kini

\footnotetext{
${ }^{14}$ Situr resmi Lembaga Penjamin Simpanan, https://www.lps.go.id.

${ }^{15}$ Situr resmi Lembaga Penjamin Simpanan, https://www.lps.go.id.
} 
belum ada bank syariah yang diselamatkan oleh Lembaga Penjamin Simpanan (LPS).

Selain penjaminan bank syariah, LPS juga sering kali melakukan off-site monitoring kinerja dan risiko perbankan syariah yang merupakan sebagian dari tugas LPS serta mendorong stabilitas sistem perbankan. LPS juga runtin berkomunikasi dengan pengawas bank, terutama pada bank yang memiliki aset terbesar dan bank yang menurut analisa LPS memiliki masalah pada sistem dalam menjalankan tugasnya.

\section{Jamkrindo Syariah (Jamsyar)}

Jamkrindo Syariah merupakan Badan Usaha Milik Negara yang bergerak pada bidang penjaminan pembiayaan dan merupakan pelopor penjaminan syariah di Indonesia. Jamkrindo Syariah memulai kegiatan penjaminan atas pembiayaan lembaga keuangan syariah pada tahun 1997, melalui kerjasama Bank Muamalat. Jamkrindo syariah didirikan pada tanggal 19 September 2014 dengan visi "menjadi perusahaan penjaminan syariah terdepan yang mendukung perkembangan perekonomian nasional.” 16 Jamkrindo Syariah juga memiliki fungsi yaitu melakukan penjaminan syariah untuk

\footnotetext{
${ }^{16}$ PT Jamkrindo Syariah. Situs resmi BUMN https://bumn.go.id.
}

pengembangan bisnis dan usaha pada perbankan syariah di Indonesia. Penjaminan pembiayaan ke Jamsyar diharapkan dapat memitigasi risiko nasabah gagal bayar. ${ }^{17}$ Kegagalan bayar (non performance financing) adalah hal yang sangat diperhatikan secara serius oleh bank syariah, sebab hal tersebut dapat mengganggu kinerja keuangan bank syariah. $^{18}$

Berdasarkan peran dan fungsi masingmasing lembaga fasilitator bank syariah di atas menunjukkan bahwa bank syariah sebagai lembaga keuangan harus sangat hati-hati (prudential principal) dalam menjalankan kegiatan usahanya. BI sebagai bank sentral bertugas mengawasi bank syariah secara makro prudensial, sedangkan OJK bertugas mengawasi bank syariah secara mikro prudensial, pengawasan bank syariah secara makro prudensial dan mikro prudensial sebelumnya hanya dijalankan oleh BI, setelah OJK didirikan kewenangan tersebut dibagi menjadi dua. Tugas OJK lebih spesifik mengawasi bank syariah pada sisi

17 Liga Nugraha Rani. (2018). Dampak Penjaminan Syariah Pada Kesehatan Pembiayaan Bank Syariah. Al Tijarah, 4/2. hlm. 38.

18 Sujian Suretno. (t.t.). Pelaksanaan Musyarakah di Bank Syariah Mandiri, Kajian Prinsip Keadilan dan Kepatuhan Syariah. Cirebon, Jawa Barat: Nusa Litera Inspirasi. hlm. 31. 
kesehatan kinerja keuangannya. OJK harus memastikan bahwa bank syariah tidak mengalami non performing financing dalam jumlah yang tinggi, karena apabila suatu bank syariah banyak mengalami NPF maka dapat berdampak sistemik dan mengacaukan sistem keuangan nasional. Kemudian DSN-MUI bertugas untuk menerbitkan fatwa terkait dengan produkproduk bank syariah, baik produk penghimpunan dana, produk pembiayaan, dan produk jasa keuangan bank. Produkproduk yang digulirkan harus didasari oleh fatwa DSN-MUI. DSN-MUI juga harus merespon model bisnis bank syariah yang terus mengalami perkembangan. Kemudian tugas DPS, DPS merupakan wakil dari DSN-MUI, anggota DPS di bank syariah sebagian besar berasal dari unsur anggota DSN-MUI, fenomena tersebut dipandang wajar karena kapasitas dan kompetensi anggota DPS harus memahami dan menguasai fatwa-fatwa DSN-MUI terkait dengan produk-produk bank syariah. DPS bertugas memberikan nasehat dan arahan kepada direksi bank syariah, dan memastikan bahwa bank syariah dalam menjalankan kegiatan usahanya berdasarkan fatwa-fatwa dari DSN-MUI. Inti tugas DPS adalah menjamin bahwa bank syariah comply (patuh aturan). IAI memiliki peran untuk mengatur laporan keuangan bank syariah sesuai dengan PSAK-PSAK syariah. Banyaknya akad pada bank syariah sangat menentukan bagaimana cara menyajikan, menilai, dan mengukur suatu transaksi keuangan yang terjadi. Untuk itu IAI memiliki peran yang sangat strategis dalam membuat model laporan keuangan syariah pada bank syariah. Laporan keuangan syariah pada bank syariah harus mengandung unsur persaudaraan (ukhuwah), keadilan ('adalah), kemaslahatan (maslahah), keseimbangan (tawazun), dan universalisme (syumuliyah). Lembaga berikutnya adalah Basyarnas. Basyarnas bertugas memfasilitasi adanya silang sengketa (dispute) yang terjadi di antara nasabah dan bank syariah. Basyarnas akan memutus perkara pada para pihak yang bersengketa berdasarkan prinsip-prinsip hukum Islam, sehingga dengan demikian masing-masing pihak yang bersengketa akan mendapatkan keadilan dan ketentraman. Walaupun saat ini kasus silang sengket yang dialami oleh nasabah jarang diselesaikan melalui Basyarnas. Kemudian LPS dan Jamsyar. Fungsi kedua lembaga ini pada prinsipnya sama, yaitu menjamin keamanan dana bank. Perbedaannya kalau LPS menjamin dana 
simpanan sedangkan Jamsyar menjamin dana pembiayaan bank. Bank syariah harus menjaminkan dananya tersebut dalam rangka untuk memitigasi risiko yang terjadi.

Dengan demikian dapat dipahami bahwa bank syariah sebagai lembaga keuangan adalah lembaga yang sangat prudent dalam menjalankan bisnisnya, mengingat dana yang dikelola oleh bank sangatlah besar, dan pertanggungjawabannya sangat berat, di sisi lain bank juga harus sehat sehingga kegiatan penyaluran pembiayaannya dapat memberikan kontribusi yang besar bagi pengembangan ekonomi masyarakat.

Selain itu masih banyak sekali lembaga-lembaga pendukung bank syariah lainnya seperti ASBISINDO, MES, IAEI, PKES, AASI, FOSSeI, dan FOZ, lembagalembaga tersebut dapat dijadikan sebagai sarana komunikasi dengan masyarakat seperti dalam rangka meningkatkan pemahaman masyarkat terhadap produk bank syariah yang sudah terkonseptualisasi dalam aturan yang mapan. ${ }^{19}$

\section{E. KESIMPULAN}

Berdasarkan penelitian yang penulis kaji di atas dapat disimpulkan bahwa

\footnotetext{
${ }^{19}$ Sujian Suretno. (thn ???). hlm. 283.
}

lembaga-lembaga fasilitator bank syariah otoritas berada pada Dewan Syariah Nasional MUI akan tetapi secara kelembagaan Bank Indonesia yang memiliki wewenang tertinggi dari sisi pengawasan dan sisi operasional pada lembaga keuangan. Lembaga fasilitator yang memiliki kaitan yang erat pada lembaga keuangan khususnya perbankan syariah meliputi Bank Indonesia (BI), Otoritas Jasa Keuangan (OJK), Dewan Syariah Nasional Majlis Ulama Indonesia (DSN MUI), Ikatan Akuntansi Indonesia (IAI), Dewan Pengawas Syari'ah (DPS), Badan Abritrase Syari'ah Nasional (Basyarnas), Lembaga Penjamin Simpanan (LPS), dan Jamkrindo Syariah. Dan setiap lembaga memiliki wewenang, fungsi dan tugas yang berbeda dalam mengawasi, mengawal, melindungi, menyelesaikan permasalahan, pembuatan fatwa dan peraturan mengenai sistem kerja pada perbankan syariah. Yang menjadi fungsi utamanya ialah untuk membantu melancarkan peningkatan perekonomian syariah di Indonesia khususnya memperkuat perusahaan perbankan syariah di Indonesia.

Banyaknya lembaga fasilitator bank syariah semakin memperjelas kedudukan bank syariah sebagai lembaga intermediasi 
keuangan yang sangat hati-hati (prudent) dalam menjalankan kegiatan usahanya. Bank syariah memiliki tanggungjawab yang sangat berat dalam mengelola dana nasabah, karena dana yang dikelola oleh satu bank syariah saja minimal berjumalah 1 triliun rupiah, terlebih lagi bank-bank syariah yang masuk dalam kategorisasi buku tiga, jumlah dana nasabah yang dikelola mencapai paling sedikit 3 triliun. Wajar jika bank syariah sangat hati-hati mengelola kegiatan usahanya dengan memperhatikan aturan main terkait bank syariah itu sendiri dan aturan-aturan yang mengikat bank syariah dari beberapa lembaga fasilitator bank syariah.

Dengan demikian diharpkan bank syariah dapat menjalankan kegiatan usahanya dengan baik yang terindikasikan dari beberapa indikator: 1) bank syariah memiliki kinerja keuangan yang sehat, 2) bank syariah patuh terhadap prinsip syariah, 3) bank syariah memiliki tata kelola perusahaan yang baik, 4) bank syariah menjamin keamanan dana simpanan nasabah sebagai bentuk pertanggungjawaban untuk memitigasi risiko simpanan dana nasabah baik yang berupa tabungan dan deposito. 4) bank syariah juga menjamin dana pembiyaan yang disalurkan kepada nasabah sebagai bentuk pertanggungjawaban untuk memitigasi risiko terkait dengan dana bank yang disalurkan kepada nasabah dalam berbagai bentuk pembiayaan. Seluruh produk pembiayaan telah dijaminkan dengan baik oleh bank syariah., dan 5) bank syariah menjadi agen pembangunan nasional dalam pembiayaan sektor riil sehingga dapat mendorong peningkatan perekonomian nasional.

\section{DAFTAR PUSTAKA}

\section{Sumber dari Jurnal}

Hasan, H. (2012). Efektivitas Pengawasan Otoritas Jasa Keuangan Terhadap Lembaga Perbankan Syariah. Jurnal Legislasi Indonesia, 9/3.

Rani, L.N. (2018). Dampak Penjaminan Syariah Pada Kesehatan Pembiayaan Bank Syariah. Al Tijarah, 4/2.

\section{Sumber dari Buku}

Sholihin, Ahmad Ifham. 2010). Pedoman Umum Lembaga Keuangan Syariah. Jakarta: PT Gramedia.

Andri Soemitra. (2010). Bank dan Lembaga Keuangan Syariah. Jakarta: Kencana.

Undang-Undang Republik Indonesia nomer 21 Tahun 2011 tentang Otoritas Jasa Keuangan BAB I Pasal 1.

Ahmad Ifham Sholihin. (2010). Pedoman Umum Lembaga Keuangan Syariah. Jakarta: PT Gramedia Pustaka Utama.

Rizal Yaya et.al. (2009). Akuntansi Perbankan Syariah Teori dan Praktik Kontemporer. Jakarta. 
Sujian Suretno. (t.t.). Pelaksanaan Musyarakah di Bank Syariah Mandiri, Kajian Prinsip Keadilan dan Kepatuhan Syariah. Cirebon, Jawa Barat: Nusa Litera Inspirasi.

\section{Sumber dari Internet}

https://www.jurnal.id/id /blog/2017 -5faktor-penyebab-terjadinya-inflasi/,

Lima Faktor Terjadinya Inflasi, diakses pada tanggal 26 Maret 2020.

Situs resmi Bank Indonesia, https://www.bi.go.id.

Situs resmi IAI. https://iaiglobal.org.id.

Majelis Ulama Indonesia "Sejarah Basyarnas", situs resmi https://www.mui.org.id/2009.

Situr resmi Lembaga Penjamin Simpanan, https://www.lps.go.id.

Situr resmi Lembaga Penjamin Simpanan, https://www.lps.go.id.

PT Jamkrindo Syariah. Situs resmi BUMN. https://bumn.go.id. 